\title{
DOMINASI DAN KETIDAKSETARAAN HUBUNGAN KREDITOR-DEBITOR PADA SURAT PERJANJIAN PEMBIAYAAN KENDARAAN
}

\author{
Sukarno \\ Fakultas Sastra Universitas Jember \\ e-mail: msukarno08@gmail.com
}

\begin{abstract}
Abstrak
Penelitian ini bertujuan mendeskripsikan dominasi dan ketidaksetaraan hubungan antara Kreditor dan Debitor dalam Surat Perjanjian Pembiayaan Kendaraan (SPPK). Sumber data adalah dokumen SPPK yang dikeluarkan oleh PT Toyota Astra Financial Services Cabang Jember. Pengumpulan data dengan teknik simak dan catat. Analisis menggunakan kerangka teori wacana kritis. Hasil penelitian menunjukkan bahwa Kreditor sebagai pihak yang berkuasa mendominasi pemroduksian teks SPPK, mencakup: perumusan isi surat perjanjian, penataan urutan bagian-bagian, proses pembuatan, dan penandatanganan. Mengacu pada isi perjanjian, pihak Kreditor menunjukkan dominasi terhadap Debitor. Hal itu terungkap melalui pasal-pasal yang selalu berpihak dan melindungi kepentingan Kreditor serta tidak adanya pasal yang berpihak pada Debitor. Fakta tersebut membuktikan bahwa relasi sosial didominasi oleh Kreditor, sehingga terjadi hubungan yang tidak setara.
\end{abstract}

Kata kunci: Kreditor, Debitor, dominasi, ketidaksetaraan, surat perjanjian

\section{DOMINATION AND INEQUALITY OF THE CREDITOR-DEBTOR RELATIONSHIP IN THE VEHICLE FINANCING AGREEMENT LETTER}

\begin{abstract}
This study aims to describe dominance and inequality of the creditor-debtor relationship in the Vehicle Financing Agreement Letter (VFAL). The data sources were VFALs issued by PT Toyota Astra Financial Services, Jember Branch. The data were collected through reading and note taking. The analysis used the critical discourse theory framework. The results of the study show that the creditor, as the party with power, dominates the production of a VFAL text, consisting of: the formulation of agreement letter contents, the arrangement of the parts, the writing process, and the signing. Referring to the agreement contents, the creditor shows the domination over the debtor. This is indicated by the articles that always take the creditor's side and protect the creditor's interest and the fact that no articles take the debtor's side. Such a fact shows that the social relationship is dominated by the creditor, resulting in an unequal relationship.
\end{abstract}

Keywords:creditor, debtor, inequality, agreement letter

\section{PENDAHULUAN}

Dalam kehidupan sehari-hari, manusia tidak mungkin dapat memenuhi semua kebutuhannya sendiri. Setiap orang selalu memerlukan bantuan (jasa dan barang) dari orang lain, baik dengan cara saling bertukar barang (barter) atau dengan cara membeli, maupun meminjam. Hal yang sering terjadi dalam rangka memenuhi kebutuhan adalah keinginan memiliki suatu barang atau jasa yang besar tetapi dana yang dimilikinya tidak mencukupi. 
Misalnya, kebutuhan untuk memiliki tempat tinggal (rumah), kendaraan, dan sebagainya. Oleh karena keterbatasan dana dan semakin mendesaknya kebutuhan, banyak orang yang menggunakan jasa penyedia dana, seperti: bank, koperasi, jasa fasilitas pembelian kendaraan (leasing) dan sebagainya untuk memenuhi kebutuhan tersebut. Karena melibatkan dua pihak, pihak penyedia dana dan pengguna dana, peminjaman uang perlu diatur dalam surat perjanjian yang berkekuatan hukum. Surat perjanjian merupakan bagian dari teks hukum yang melingkupi dua pihak yang sedang melakukan kesepakatan atas persetujuan dan kewajiban yang telah sepakati (Sriyono, 2014).

Pada dasarnya, teks hukum dapat dibedakan menjadi tiga jenis, yakni: (1) teks legislatif, (2) teks yuridis, dan (3) teks hukum pribadi (Cao, 2007: 9). Yang termasuk teks hukum pribadi antara lain surat perjanjian atau kontrak baik yang ditulis oleh pengacara ataupun bukan oleh pengacara yang berkekuatan hukum karena surat perjanjian tersebut telah dibubuhi materai. Dengan surat perjanjian yang berkekuatan hukum, diharapkan bahwa semua pihak yang terlibat dalam perjanjian saling menepati kesepakatan yang telah dibuat. Apabila terjadi permasalahan atau perselisihan di antara mereka di kemudian hari, permasalahan itu dapat diselesaikan secara hukum.

Di antara sekian banyak surat perjanjian, salah satu di antaranya adalah surat perjanjian pembiayaan pembelian kendaraan. Dalam surat perjanjian pembiayaan pembelian kendaraan disajikan berbagai hal yang menginformasikan antara lain tentang: (1) penyebutan atas pihak pemberi pinjaman dana (Kreditor), dan pihak penerima pinjaman dana (Debitor), (2) jumlah dana yang diterima, (3) jumlah bunga yang harus dibayar berkaitan dengan peminjaman dana, (4) besar angsuran (pokok pinjaman dan bunganya) setiap bulan yang harus dibayar, (5) jangka waktu, cara, dan tempat pembayaran kembali angsuran, (6) penggunaan dana, (7) pembebanan biaya-biaya lain atas peminjaman dana tersebut, dan (8) berbagai sanksi yang timbul apabila hal-hal yang telah disepakati dalam surat perjanjian tidak dilaksanakan dengan baik (oleh Debitor). Selanjutnya, untuk mewujudkan kegiatan praktik sosial dalam surat perjanjian diperlukan bahasa yang berfungsi sebagai penyampai informasi terutama keinginan Kreditor kepada Debitor.

Pada awalnya bahasa diartikan sebagai alat untuk berkomunikasi, atau bahasa memiliki fungsi informatif, yakni sebagai alat penyampai informasi seseorang (penutur) kepada orang lain (mitratutur) (Leech, 1983: 47). Namun dalam perkembangannya, bahasa tidak hanya berhenti pada pengertian sekadar untuk berkomunikasi (fungsi informatif), tetapi bahasa juga dipakai sebagai media untuk melakukan sesuatu (Wetterell, Taylor, dan Simeon, 2001: 3). Bahkan bahasa dapat dipandang sebagai alat untuk menjalankan kekuasaan dalam rangka mencapai tujuan yang diinginkan (penutur). Oleh karena itu, bahasa dapat digunakan untuk beragam fungsi seperti untuk memerintah, memengaruhi, membujuk mitratutur untuk melakukan sesuatu, mendeskripsikan, mengiba, memanipulasi dan sebagainya. Hal penting dalam berbahasa adalah selalu ada sesuatu yang ingin dicapai oleh si penutur (pemroduksi wacana).

Maksud pemroduksi wacana dalam tuturan/tulisannya tidak selalu disampaikankan secara jelas. Akan tetapi, maksud tersebut dapat diungkap dengan cara menganalisis teks secara kritis. Kajian yang berusaha mengungkap maksudmaksud yang terselubung dalam teks secara kritis disebut analisis wacana, yaitu sebuah upaya untuk menjelaskan realisasi sosial yang diungkapkan dalam teks yang ditengarahi terdapat penyalahgunaan kekuasaan, dominasi, atau ketidaksetaraan (van Dijk, 2005: 252), atau 
terdapat kecenderungan untuk memperoleh tujuan tertentu yang diinginkan (Mardikantoro, 2014).

Pendekatan kajian kritis menempatkan wacana sebagai suatu kekuatan ' $p o w e r$ ' (Asher dan Simpson, 2006: 940), sehingga wacana juga dipandang sebagai cermin suatu relasi kekuasaan dalam praktek sosial (Renkema, 2004:282). Oleh karena itu, dalam wacana kritis, wacana tidak hanya dipandang sebagai suatu studi bahasa biasa, melainkan juga dipahami sebagai suatu bentuk praktik sosial (Fairclaugh dan Wodak, 1997). Dalam praktik sosial, seseorang atau sekelompok orang dapat berwacana untuk mencapai tujuan yang diinginkan, termasuk untuk menjalankan kekuasaannya terhadap pihak lain yang dianggap tidak berdaya (Subagyo, 2010). Dalam kegiatan berwacana seperti yang terjadi pada surat perjanjian pembiyaan kendaraan dapat menampilkan efek ideologi, yakni memproduksi dan mereproduksi hubungan kekuasaan yang tidak setara (unequal relationship) atau terjadi hubungan kekuasaan dan dominasi (van Dijk, 2005: 254) antara pihak yang lebih kuat atau yang berkuasa (thepowerful) secara finansial terhadap pihak yang lebih lemah atau tak berdaya secara finansial. Oleh karena itu, studi ini bertujuan untuk mengungkap dominasi dan ketidaksetaraan kekuasaan yang terjadi dalam hubungan antara Kreditor dan Debitor pada wacana surat perjanjian peminjaman dana untuk membeli kendaraan.

\section{METODE}

Data penelitian ini bersumber dari dokumen (documentary data). Menurut Denscombe (2007: 227) dokumen dapat digunakan sebagai sumber data dalam bentuk sebagaimana aslinya. Dokumen yang dijadikan sumber data pada penelitian ini adalah surat perjanjian pembayaran hutang (kredit) atas fasilitas pembelian kendaraan yang dikeluarkan oleh PT
Toyota Astra Finansial Services tanggal 31 Mei 2011 dengan nomor pelanggan: 0000432975, dan nomor perjanjian 02164711, dalam rangka pembelian kendaraan Toyota Avanza/F 61 E M/T 10. Dokumen tersebut dalam penelitian ini disebut 'Surat Perjanjian Pembiayaan Kendaraan' (selanjutnya disebut SPPK).

Pengumpulan data pada penelitian ini dilakukan dengan metode pustaka yaitu dengan memanfaatkan sumber-sumber tertulis (dokumen, SPPK) untuk mendapatkan data yang diinginkan (Subroto, 1992:42), dan dilakukan dengan teknik simak dan catat (Sudaryanto, 2003: 5). Setelah dilakukan pengamatan secara menyeluruh atas dokumen SPPK, dilakukan pengidentifikasian data kebahasaan yang berupa kata, frasa, dan penggalan wacana (kalimat atau penggalan kalimat) pada SPPK. Hasil identifikasi tersebut dicatat dan disusun berdasarkan urutan kebutuhan analisis. Desain ini sengaja dipilih untuk memperoleh kerangka kerja dalam rangka mengumpulkan, menganalisis, dan membahas data guna mencapai tujuan penelitian (Creswell dan Clark, 2011) yakni untuk mengungkap dominasi dan ketidaksetaraan hubungan antara Kreditor dan Debitor dalam SPPK. Karena berupa kata, frasa, dan penggalan wacana atau uraian, data penelitian ini disebut data kualitatif (Denscombe, 2007: 286). Sesuai dengan sifat data (kualitatif), analisis pada penelitian ini juga bersifat deskriptif kualitatif kritis. Pendekatan kritis pada analisis ini dilakukan dengan cara menempatkan wacana sebagai power (kekuasaan) (Asher dan Simpson, 2006: 940) untuk mencapai tujuan yang hendak dicapai. Dalam kajian ini, peneliti telah menempatkan persepsinya bahwa telah terjadi 'ketidakberesan sosial' melalui produksi hubungan kekuasaan yang tidak seimbang antara Kreditor dan Debitor dalam SPPK. 


\section{HASIL DAN PEMBAHASAN}

Analisis wacana kritis memanfaatkan bahasa dalam teks yang dianalisis. Bahasa yang dianalisis tidak sekedar menggambarkan aspek-aspek kebahasaan yang terjadi dalam teks, tetapi juga menunjukkan hubungan antara teks dengan konteksnya (Halliday dan Hasan, 1989:10). Dalam hal ini, bahasa dikaji untuk mengungkap tujuan-tujuan yanghendak dicapai oleh pemroduksi wacana termasuk di dalamnya pengungkapan wacana sebagai realisasi untuk melakukan praktik kekuasaan (Mardikantoro, 2014). Menurut van Dijk (dalam Keshavarz dan Zonoozi, 2011), analisis wacana kritis tidak memiliki suatu kerangka teori atau metodologi yang baku, sebaliknya analisis ini dipandang sebagai paradigma bersama yang dapat menaungi berbagai pendekatan yang re-levan, seperti: pragmatik, analisis percakapan, analisis narasi, retorika, stilistik, sosiolinguistik, etnografi komunikasi, analisis media, dan lain-lainnya (van Dijk, 2005: 252) dari pada hanya berpaku pada satu kerangka teori tertentu.

Dalam studi ini, wacana dikaji secara kritis dari konteks yang menaungi wacana SPPK. Menurut Halliday dan Hasan (1989: 10) wacana adalah bahasa yang sedang menjalankan fungsinya (language in use), yakni bahasa yang sedangmenjalankan tugas tertentu dalam konteks situasi tertentu, yang beroposisi dengan kalimat-kalimat lepas yang tidak mengacu pada konteks situasi tertentu. Konteks situasi memiliki tiga unsur utama yaitu: medan wacana (field of discourse), pelibat wacana (tenor of discourse) dan sarana wacana (mode of discourse) (Thompson, 2004: 30). Medan wacana mengacu pada hal yang sedang terjadi atau sesuatu yang sedang diperbincangkan, pelibat wacana menunjuk pada orang-orang yang ambil bagian dalam perbincangan, yakni: sifat, kedudukan, dan peran mereka dalam perbincangan, dan sarana wacana adalah bagian yang diperankan oleh bahasa da- lam perbincangan (Halliday dan Hasan, 1989: 12).

Ciri-ciri medan pada wacana SPPK dapat diungkap dari analisis transitivitas dan kompleksitas. Hasil analisis transitivitas menunjukkan bahwa hal yang diperbincangkan dalam wacana SPPK berkaitan dengan: hak, kewajiban, waktu, tempat serta sanksi atas pemberian kredit oleh Kreditor kepada Debitor untuk melakukan pembelian kendaraan. Sementara itu, analisis kompleksitas menunjukkan bahwa klausa-klausa (istilah untuk kalimat pada tata bahasa fungsional atau systemic functional linguistics, Halliday, 2004) yang digunakan pada wacana SPPK didominasi oleh klausa-klausa kompleks (kalimat majemuk) daripada klausa simpleks (kalimat sederhana). Hal ini menunjukkan bahwa apa yang diperbincangkan dalam SPPK diungkapkan sejelas mungkin agar tidak terjadi salah pengertian atau penafsiran ganda.

Dalam wacana SPPK, terdapat dua pelibat utama: Kreditor, pihak pemberi kredit (Tim Pustaka Phonix, 2010), yaitu pihak yang menyediakan dana untuk membeli kendaraan, dan Debitor, pihak penerima kredit (Tim Pustaka Phonix, 2010), yaitu pihak yang menerima dana untuk melakukan pembelian kendaraan. Kedua pelibat pada SPPK, Kreditor dan Debitor, memiliki ciri sifat pelibat yang berlawanan. Kreditor bersifat sangat berkuasa. Dia berkuasa mengatur, menentukan, dan menetapkan segala hal terkait dengan segala sesuatu yang diperbincangkan pada wacana SPPK. Sebaliknya, Debitor bersifat sangat lemah, bahkan tidak berdaya, sehingga selalu menerima semua hal yang diatur, ditentukan, dan ditetapkan oleh Kreditor. Dengan kata lain, hubungan antarpelibat pada wacana SPPK bersifat tidak setara (unequal) karena pihak yang satu (Kreditor) mendominasi pihak yang lainnya (Debitor).

Unsur konteks situasi yang ketiga adalah peran bahasa dalam perbincangan. 
Dalam SPPK, bahasa memegang peran yang sangat penting yang diwujudkan dalam beberapa hal berikut. Pertama, jenis teks yang dipilih selalu dalam bentuk bahasa tulis, bukan bahasa lisan. Hal ini dimaksudkan agar surat perjanjian tersebut sebagai dokumen perjanjian utang piutang tidak mudah dilupakan dan halhal yang tidak sesuai dengan keinginan pelibat wacana (terutama keinginan Kreditor) dapat dihindari. Kedua, bahasa yang dipilih adalah bahasa yang resmi, dan memiliki kekuatan hukum karena itu perlu dilakukan pembubuhan materi. Ketiga, untuk mewujudkan keinginan pelibat wacana (terutama Kreditor), selalu dipilih istilah-istilah yang tegas dan jelas, seperti penggunaan kata 'wajib', 'hak', 'sanksi', 'denda', 'jatuh tempo' dan sebagainya.

\section{Struktur SPPK}

Setiap teks mempunyai kekhususan tersendiri, demikian pula dengan teks hukum laras perjanjian (Sriyono, 2014). SPPK sebagai teks hukum laras perjanjian yang dikeluarkan oleh PT Astra Finansial Services secara keseluruhan terdiri dari tiga bagian yang merupakan suatu kesatuan yang tidak terpisahkan, yaitu: (1) Perjanjian Pembiayaan, (2) Surat Pernyataan Bersama, dan (3) Syarat dan Ketentuan Umum Perjanjian Pembiayaan. Bagian pertama, perjanjian pembiyaan, berisi pihak-pihak yang mengikat janji, yakni Kepala bagian penjualan (Sale head) yang selanjutnya disebut Kreditor, dan pihak yang menerima jasa pembiayaan pembeliaan kendaraan bermotor yang selanjutnya disebut Debitor. Dalam bagian perjanjian pembiayaan terdapat lima hal yang diperjanjikan, yakni: identitas (jenis/ merk/model/tahun) kendaraan yang dibeli, jumlah hutang keseluruhan (hutang pokok dan bunga), jangka waktu pengembalian pinjaman beserta bunganya, jaminan pembayaran, dan tanggal efektif berlakunya perjanjian. Bagian kedua, surat pernyataan bersama, berisikan sembilan poin, yang isinya hampir sama dengan isi perjanjian pembiayaan, unsur tambahannya adalah kesepakatan atas penyerahan dan penyimpanan buku pemilik kendaraan bermotor (BPKB) oleh Debitor kepada Kreditor sampai kewajiban Debitor dipenuhi seluruhnya, dan kesepakatan bahwa kendaraan dan BPKB tidak akan dialihkan kepada pihak ketiga.

Bagian ketiga, syarat dan ketentuan umum perjanjian pembiayaan, merupakan bagian yang paling menentukan karena pada bagian ini semua keinginan Kreditor dituangkan, dan pada bagian inilah praktik sosial berwacana yang melibatkan unjuk kekuatan (dominasi) Kreditor terhadap Debitor, dan ketidaksetaraan (unequality) hubungan direalisasikan. Syarat dan ketentuan umum pada bagian ketiga ini dijabarkan dalam bentuk pasal-pasal dan dirinci ke dalam ayat-ayat. Bagian ini terdiri dari 15 pasal dan beberapa pasal penting dijabarkan lagi dalam ayat-ayat, misalnya pasal 4 tentang pembayaran kembali dijabarkan menjadi 7 ayat, pasal 6 tentang penguasaan barang dijabarkan menjadi 10 ayat, dan pasal 7 tentang ansuransi dijabarkan ke dalam 11 ayat. Penjabaran paling rinci terjadi pada pasal 8 tentang peristiwa wanprestasi, yang terdiri dari tiga sub pasal $(8.1,8.2$, dan 8.3) dan dijabarkan ke dalam 30 ayat.

Selanjutnya, penataan atau tata urutan penyajian ketiga bagian pada SPPK cukup menarik untuk dikritisi. Bagian yang memerlukan tanda tangan persetujuan ditempatkan di bagian awal (bagian pertama dan kedua). Pada dua bagian ini belum ditampilkan hal-hal yang mengatur kewajiban-kewajiban Debitor secara rinci, termasuk: denda, sanksi, dan biaya administrasi. Dengan demikian ada kecenderungan bahwa Debitor dengan mudah akan menandatangani surat perjanjian tersebut dengan hanya membaca kedua bagian itu yang isinya masih bersifat netral dan normatif. Beberapa hari kemudian, 
setelah menerima salinan SPPK, Debitor biasanya baru menyadari isi SPPK yang dijabarkan secara rinci pada bagian ketiga, padahal mereka sudah terlanjur menandatanganinya. Secara fair seharusnya, draf SPPK, terutama bagian yang ketiga yang berisi syarat dan ketentuan umum yang menjabarkan semua kewajiban Debitor termasuk resiko yang harus ditanggung, diberikan kepada calon Debitor beberapa hari sebelum hari penandatanganan SPPK tersebut. Dengan demikian, Debitor memiliki cukup waktu untuk mempelajari isi SPPK dan Debitor dapat mengajukan keberatan atau perubahan atas hal-hal yang dianggap memberatkan atau kurang wajar.

\section{Dominasi dan Ketidaksetaraan Hubungan}

Uraian konteks situasi yang melingkupi wacana SPPK tersebut di atas memaparkan bahwa medan wacana bercirikan tentang hak dan kewajiban Kreditor dan Debitor atas pencairan dana untuk membeli kendaraan. Ciri pelibatnya menunjukkan bahwa Kreditor merupakan pelibat yang lebih berkuasa (more powerful) daripada Debitor dalam hal mengatur segala sesuatu yang menyangkut isi surat perjanjian tersebut. Praktik sosial yang menggambarkan dominasi dan ketidaksetaraan hubungan dalam surat perjanjian ini diwujudkan dalam peran bahasa yang sengaja dirancang oleh pemroduksi teks (Kreditor) berupa pilihan kata, frasa, gramatika, serta struktur teks yang secara keseluruhan cenderung menguntungkan pihak Kreditor, bahkan hak-hak Debitor terabaikan.

\section{Pilihan Kata, dan Frasa}

Data kebahasaan yang berupa pilihan kata dan frasa yang menunjukkan dominasi dan ketidaksetaraan relasi sosial antara Kreditor dan Debitor pada SPPK disajikan pada Tabel 1.

Berdasarkan data kebahasaan yang berupa pilihan dan penggunaan kata dan frasa pada wacana SPPK (sebagaimana dikutip pada Tabel 1), tampak jelas bahwa Kreditor sangat mendominasi atas isi perjanjian yang pada dasarnya cenderung mengarah pada kepentingan Kreditor dan mengabaikan hal-hal yang merupakan hak Debitor. Mengacu pada Tabel 1, setiap data kebahasaan yang ditujukan pada Kreditor selalu bernuansa positif yang menempatkan Kreditor sebagai pihak berkuasa. Dalam bentuk verba, data kebahasaan tersebut misalnya: berhak, menyetujui, mengijinkan, menentukan, menolak, serta menyesuaikan, dan dalam bentuk frasa verba, seperti: melakukan perubahan, memberikan persetujuan, meminta keterangan. Bahkan hampir setiap hal yang mengacu pada Kreditor selalu bernuansa 'hak'. Barang kali, ungkapan yang mengacu pada 'kewajiban' bagi Kreditor hanyalah 'menyerahkan barang' yang dibeli kepada Debitor.

Sebaliknya, data kebahasaan yang ditujukan kepada Debitor lebih berupa kewajiban-kewajiban yang harus dilaksanakan beserta sanksi yang harus ditanggung (seperti penalti, denda keterlambatan, biaya administrasi) apabila Debitor tidak memenuhi kewajibannya. Dalam bentuk verba, data kebahasaan tersebut misalnya berwujud: berkewajiban, membayar, menyerahkan, mengikuti, menjaminkan, serta mengansuransikan, dan dalam bentuk frasa verba seperti:memenuhi kewajiban, memberi kuasa. Dalam bentuk nomina, data tersebut berupa: kewajiban, penalti, denda, bunga, teguran, serta kerugian, dan dalam bentuk frasa nomina misalnya: biaya administrasi, denda keterlambatan, harta kekayaan Debitor. Bahkan, hampir tidak terdapat data kebahasaan yang menunjukkan hak Debitor, kecuali 'ia dapat menggunakan barang atau kendaraan' yang dibelinya sesuai dengan kebutuhan. Pemberian 'hak' ini pun dibatasi oleh pernyataan bahwa penggunaan kendaraan harus dihentikan apabila mendapat pemberitahuan secara tertulis oleh Kreditor (pasal 6, ayat 6.4). 
Tabel 1. Pilihan Kata dan Frasa pada SPPK

\begin{tabular}{|c|c|c|c|}
\hline \multirow{2}{*}{$\begin{array}{c}\text { Jenis kata\& } \\
\text { Frasa }\end{array}$} & \multicolumn{3}{|c|}{ Ditujukan kepada } \\
\hline & Kreditor & Debitor & Keduanya \\
\hline Verba & $\begin{array}{l}\text { berhak, menerima, } \\
\text { menyetujui, mengijinkan, } \\
\text { menyesuaikan, menentukan, } \\
\text { menolak, }\end{array}$ & $\begin{array}{l}\text { berkewajiban, membayar, menjaminkan, } \\
\text { menyerahkan, mengasuransikan, membe- } \\
\text { rikan (kuasa), mengikuti, melunasi, }\end{array}$ & $\begin{array}{l}\text { Bersepakat, } \\
\text { berjanji, }\end{array}$ \\
\hline Frasa Verba & $\begin{array}{l}\text { ditetapkan/ditentukan oleh } \\
\text { Kreditor, memberikan perse- } \\
\text { tujuan, melakukan perubahan, } \\
\text { meminta keterangan, menye- } \\
\text { rahkan barang, }\end{array}$ & $\begin{array}{l}\text { memenuhi kewajiban, menyerahkan } \\
\text { penguasaan (atas barang), (tidak dapat) } \\
\text { mengalihkan hak dan kewajibannya, } \\
\text { memberi kuasa, }\end{array}$ & \\
\hline Nomina & Persetujuan, penyesuaian, hak & $\begin{array}{l}\text { kewajiban, penalti, denda, bunga, ganti } \\
\text { rugi, kerugian, penyesuaian, bukti, } \\
\text { ansuransi, kelalaian, teguran, angsuran, } \\
\text { tuntutan, pinjaman, pelunasan, }\end{array}$ & \\
\hline Frasa nomina & $\begin{array}{l}\text { Persetujuan tertulis dari } \\
\text { Kreditor, }\end{array}$ & $\begin{array}{l}\text { biaya administrasi, persyaratan pencairan } \\
\text { fasilitas, denda keterlambatan, jatuh } \\
\text { tempo pembayaran, harta kekayaan } \\
\text { Debitor, }\end{array}$ & $\begin{array}{l}\text { Dokumen } \\
\text { kendaraan }\end{array}$ \\
\hline Adjektiva & & $\begin{array}{l}\text { terlambat, mutlak, seluruh, semua, } \\
\text { tertulis, }\end{array}$ & \\
\hline Frasa & & tepat waktu, tanpa syarat, yang tidak & \\
\hline Adjektiva & & terpisahkan, secara tertulis, & \\
\hline Frasa & & sebelum waktu jatuh tempo, selambat- & \\
\hline Adverba & & lambatnya dalam waktu dua minggu, & \\
\hline
\end{tabular}

\section{Penggalan Wacana yang Mengarah pada Dominasi dan Ketidaksetaraan}

Bentuk dominasi dan ketidaksetaraan antara Kreditor dan Debitor secara lengkap dapat diungkap melalui klausaklausa yang menguraikan syarat dan ketentuan umum pada bagian ketiga SPPK. Temuan data kebahasaan berupa klausa dalam SPPK disajikan dan dibahas dalam upaya mengungkap dominasi dan ketidaksetaraan tersebut. Dalam SPPK, Kreditor selalu mengutamakan hak-hak dan menyembunyikan kewajiban, seperti tampak pada data di bawah ini.

(1) Apabila terjadi tindakan moneter dan/ atau di bidang-bidang yang lain oleh Pemerintah RI yang berakibat langsung pada perjanjian ini, Kreditor berhak menyesuaikan jumlah kewajiban pembayaran Debitor kepada Kreditor ... (pasal 4, ayat 4.4).
(2) Semua pembayaran harus dilakukan dengan cara, di tempat, dan waktu yang ditetapkan oleh Kreditor (pasal 4 , ayat 4.5).

(3) Setiap hari keterlambatan pembayaran angsuran ... Debitor berkewajiban membayar denda keterlambatan ... (pasal 4, ayat 4.3)

(4) Jumlah biaya, denda dan atau penalti tersebut dapat berubah sewaktuwaktu sesuai dengan kebijakan yang berlaku yang ditetapkan oleh Kreditor (pasal 4, ayat 4.7).

(5) Debitor memberi kuasa kepada Kreditor untuk membuat, menandatangani, atau melakukan pembaharuan hutang terhadap perjanjian ini yang menurut Kreditor perlu dilakukan perubahan, 
penambahan, atau pembaharuan atas perjanjian ini (pasal 12, ayat 12.1 ).

Kutipan data di atas menunjukkan betapa perkasanya Kreditor dalam menjalankan kekuasaannya. Bila terjadi perubahan kebijakan moneter seperti kenaikan suku bunga, misalnya, pihak Kreditor akan menaikkan jumlah angsuran sesuai dengan yang diinginkan, sebagaimana diungkapkan oleh data (1) Kreditor berhak menyesuaikan jumlah kewajiban pembayaran Debitor kepada Kreditor .... Padahal, besar angsuran (pengembalian pinjaman pokok dan tingkat suku bunganya) telah disepakati di awal perjanjian. Dengan demikian, pihak Kreditor tidak akan pernah menanggung kerugian sekalipun terjadi kenaikan suku bunga. Semua resiko itu selalu dibebankan kepada Debitor. Sebaliknya, tidak ada klausa yang menyatakan, misalnya bila terjadi penurunan suku bunga bank, jumlah ansuran akan diturunkan atau dihitung ulang. Hal ini menunjukkan bahwa Debitor merupakan pihak yang lemah, yang didominasi oleh Kreditor.

Dominasi Kreditor terhadap Debitor dapat pula diungkap melalui data (2), (3), dan (4). Pertama, segala tatacara yang terkait dengan pembayaran angsuran, seperti: cara, tempat, dan waktu pembayaran diatur oleh Kreditor, data (2). Berikutnya apabila Debitor melakukan suatu kesalahan, misalnya terjadi kelalaian atau keterlambatan pembayaran angsuran, akan dikenakan denda atau penalti. Bahkan jumlah biaya, denda atau penalti yang dikenakan kepada Debitor dapat diubahubah sesuai dengan yang diinginkan Kreditor, data (4), tanpa memperhatikan keberatan ataupun pendapat dari Debitor. Mengapa denda dan atau penalti tidak dirundingkan atau dibicarakan bersama antara Kreditor dan Debitor? Sebaliknya, bagaimana bila pihak Kreditor yang melakukan kelalaian, apa sanksinya?
Selanjutnya, bukti nyata bahwa Kreditor menjalankan kekuasaannya kepada Kreditor sebagai pihak yang lemah ditunjukkanoleh data (5). Dalam hal ini, Kreditor meminta Debitor untuk melimpahkan kekuasaan kepada Kreditor guna melakukan perubahan-perubahan atas isi perjanjian sesuai dengan keinginan atau kepentingan Kreditor, tanpa memperhatikan kepentingan Debitor. Kelima contoh data di atas telah menunjukkan dan membuktikan betapa kuasanya (thepowerfulness) Kreditor terhadap Debitor karena semua kepentingan Kreditor selalu terakomodasi. Sebaliknya, sebagai pihak yang lemah, tak berdaya, tidak memiliki nilai tawar, Debitor merupakan pihak yang selalu menanggung segala resiko yang mungkin terjadi atas pasal-pasal pada SPPK tersebut.

Bila diperhatikan pasal-pasal yang mengacu kepada Kreditor merupakan pasal-pasal yang selalu mengedapankan hak-hak Kreditor. Bahkan tidak ada kewajiban Kreditor yang tertuang dalam surat perjanjian. Hak-hak Kreditor dalam SPPK secara otomatis menjadi kewajiban bagi Debitor. Kewajiban-kewajiban yang harus dilaksanakan oleh Debitor merupakan perisai yang memproteksi semua kemungkinan yang diperkirakan dapat merugikan Kreditor. Sebaliknya bila dicermati, pasal-pasal yang mengacu kepada Kreditor tidak ada yang menjadi perisai bagi kepentingan Debitor. Bahkan Debitor selalu dihadapkan pada kewajibankewajiban yang selalu dibentengi dengan sanksi-sanksi apabila Debitor tidak dapat melaksanakan kewajibannya kepada Kreditor.

Dalam hal kewajiban, Debitor harus mengutamakan pelaksaknaan kewajibankewajibannya, yang kewajiban-kewajiban tersebut selalu menguntungkan Kreditor. Hal ini dapat diungkap dari bunyi pasal 4 , ayat 4.2 data (6), sebagai berikut. 
(6) Debitor berkewajiban mendahulukan setiap kewajiban ... (pasal 4, ayat 4.2)

Salah satu kewajiban tersebut, misalnya, kewajiban mengembalikan dana yang digunakan untuk membeli kendaraan. Pembayaran kembali dana tersebut dilakukan dengan cara mengangsur, pokok pinjaman beserta bunga, yang besarnya ditetapkan oleh Kreditor secara sepihak. Di samping itu, masih banyak kewajiban yang harus dilakukan oleh Debitor yang ditetapkan secara sepihak oleh Kreditor. Misalnya, masalah jatuh tempo, cara, tempat, dan waktu pembayaran, serta sanksi bila terjadi keterlambatan pembayaran, seperti terlihat pada data di bawah ini.

(7) Jika hari jatuh tempo bukan pada hari kerja, maka pembayaran harus dilakukan pada hari kerja sebelum jatuh tempo ... (pasal 4, ayat 4.2).

(8) ... untuk setiap keterlambatan pembayaran ..., Debitor berkewajiban membayar denda keterlambatan, dan biaya administrasi kepada Kreditor ... (pasal 4, ayat 4.3).

Dalam hal keterlambatan, Debitor perlu membayar denda merupakan hal yang wajar, tetapi mengapa masih harus membayar biaya administrasi. Sebaliknya, bagaimana jika Debitor melakukan pembayaran lebih awal (daripada masa jatuh tempo), apakah dia diberikan discount? Berbagai kewajiban lainnya terkait dengan barang (kendaraan) yang telah diterima oleh Debitor, antara lain, Debitor diwajibkan untuk mengansuransikan kendaraan tersebut, bahkan perusahaan ansuransinya pun ditentukan oleh Kreditor, seperti yang terungkap pada data di bawah ini.

(9) Debitor wajib menjaminkan barang yang diperolehnya atas pinjaman yang diberikan oleh Kreditor (pasal 5 , ayat 5.1)
(10) Atas beban Debitor, barang wajib diansuransikan pada perusahaan yang ditunjuk oleh Kreditor (pasal 7, ayat 7.1)

Dalam hal penunjukan perusahaan ansuransi, terjadi keanehan yang mempertontonkan betapa kuasanya Kreditor terhadap Debitor. Di satu sisi, yang menentukan (menunjuk) perusahaan asuransi adalah Kreditor, tetapi di sisi yang lain apabila terjadi permasalahan dengan ansuransi yang harus menanggungnya adalah Debitor. Hal ini dapat diungkap dari data (11) di bawah ini.

(11) Apabila barang yang diansuransikan tuntuan ganti ruginya ditolak oleh Perusahaan Ansuransi, maka Debitor berjanji ... untuk memikul dan menanggung sepenuhnya atas segala resiko yang terjadi pada barang dan atau tuntutan pihak ketiga ... (pasal 7, ayat 7.5).

Salah satu dari sedikit hak yang diberikan kepada Debitor oleh Kreditor adalah Debitor dapat melunasi hutang sebelum masa angsurannya berakhir yang disebut pelunasan yang dipercepat. Namun demikian, tatacara dan aturan yang diberlakukan untuk pelunasan hutang, sekali lagi, ditentukan/diatur oleh Kreditor. Misalnya, Debitor hanya dapat melunasi hutangnya tersebut apabila telah mendapat persetujuan dari Kreditor. Selanjutnya, hal yang janggal dalam hal pelunasan hutang yang dipercepat adalah Debitor dikenakan penalti sebesar 5\% dari sisa pokokhutang, membayar bunga berjalan, dan biaya administrasi, seperti terungkap dari data (12) di bawah ini.

(12) Atas persetujuan Kreditor, Debitor dapat melunasi baik seluruh atau sebagian hutangnya kepada Kreditor di luar ketentuan jangka waktu pengembalian hutang (pelunasan dipercepat). 
Debitor wajib membayar sejumlah uang yang disetujui Kreditor dalam rangka pelunasan dipercepat ditambah (i) penalti sebesar 5\% dari sisa pokok hutang, (ii) bunga berjalan, dan biaya administrasi sebesar Rp 250.000 (pasal 4, ayat 4.7)

Ada hal-hal penting yang perlu dikritisi atau dipertanyakan berkaitan dengan pelunasan hutang yang dipercepat. Pelunasan hutang yang dipercepat seharusnya dinilai sebagai suatu prestasi yang baik atas perilaku atau tanggung jawab Debitor, sebagai oposisi dari kelalaian dan atau keterlambatan pembayaran angsuran. Pelunasan hutang yang dipercepat juga dapat dipandang sebagai bentuk oposisi dari peristiwa wanprestasi yang diungkapkan pada pasal 8 SPPK. Kenyataan yang dialami oleh Debitor yang melakukan pelunasan hutang yang dipercepat adalah dikenakan penalti atau hukuman dengan membayar sebesar 5\% dari sisa pokok hutang, pembayaran bunga berjalan, dan membayar biaya administrasi. Istilah 'penalti' yang berasal dari bahasa Inggris penalty berarti hukuman atas suatu tindakan yang salah (Hornby, 1982: 619). Hukuman pada umumnya diberikan kepada orang yang bersalah atau pihak yang tidak menjalankan kewajibannya. Apakah melakukan pelunasan hutang yang dipercepat (yang juga disetujui oleh Kreditor dan dibenarkan oleh SPPK) dapat dikategorikan sebagai tindakan yang bersalah, tidak melaksankan kewajibannya, atau tindakan wanprestasi, sehingga Debitor harus dikenai penalti atau hukuman?

Di samping membayar penalti, orang yang melakukan pelunasan hutang yang dipercepat juga masih harus membayar bunga yang berjalan. Bahkan yang lebih aneh lagi ialah Debitor yang melakukan pelunasan hutang dipercepat dikenai biaya administrasi yang besarnya mencapai Rp 250.000 (dua ratus lima puluh ribu rupiah). Dalam hal ini, tidak dijelaskan mengapa diperlukan biaya adminsitrasi, untuk apa dan untuk kepentingan siapa biaya administrasi tersebut, pada hal yang bersangkutan sudah dikenakan denda dan bunga berjalan. Oleh karena itu, jarang sekali Debitor yang mau melakukan pelunasan hutang dipercepat karena yang bersangkutan harus menanggung kerugian yang lebih besar dibandingkan dengan mengangsur hutang tersebut sesuai dengan jangka waktu yang telah disepakati. Dengan demikian, dapat dikatakan bahwa melunasi hutang yang dipercepat sebenarnya bukan suatu hak yang menguntungkan Debitor, melainkan lebih merupakan hak yang menguntungkan Kreditor. Dengan kata lain, pasal dan ayat ini juga merupakan bentuk menjalankan kekuasaan oleh Kreditor terhadap Debitor melalui wacana SPPK.

Penegasan lebih lanjut bahwa Kreditor betut-betul mendominasi Debitor dapat diungkap dari data (13) berikut.

(13) Kewajiban Debitor dalam perjanjian ini adalah mutlak dan tanpa syarat sekalipun jika Debitor oleh sebab apa pun tidak dapat menggunakan barang itu.

Data di atas menunjukkan bahwa tidak ada ruang sedikit pun bagi Debitor guna mengelak dari tanggung jawab untuk melaksanakan kewajiban-kewajibannya. Sebaliknya, semua ruang yang tersedia selalu memberikan keuntungan kepada Kreditor tanpa ada ruang yang menunjukkan kewajiban yang harus dilakukan oleh Kreditor.

Pada umumnya dalam setiap surat perjanjian, kedudukan pihak-pihak yang berjanji memiliki status yang sama. Mereka seharusnya duduk bersama untuk merumuskan hal-hal yang menjadi isi surat perjanjian yang akan mengikat keduanya. Namun, hal yang terjadi pada SPPK adalah keadaan yang tidak seimbang antara pihak pertama dan 
pihak kedua dalam hal merumuskan isi perjanjian. Bahkan, proses pembuatan isi perjanjian tidak pernah dibicarakan terlebih dulu dengan melibatkan pihak Debitor. Semua klausol atau pasal-pasal yang mengikat keduanya hanya dirumuskan oleh pihak Kreditor (atau yang mewakilinya). Sebaliknya, pihak Debitor hanya diminta membubuhkan paraf pada lembar-lembar yang memuat pasal-pasal tersebut sebagai tanda bahwa Debitor telah membaca dan mengerti isinya (walaupun pada kenyataannya tidak diberi waktu untuk membacanya), serta membubuhkan tanda tangan pada akhir lembar surat perjanjian tersebut sebagai bukti bahwa Debitor telah menyetujui untuk mengikatkan diri pada surat perjanjian tersebut. Ketidaksetaraan hubungan sebagai dampak dominasi praktik sosial pada wacana SPPK terjadi karena Kreditor merasa posisinya lebih berkuasa (secara finansial) daripada Debitor.

Karena sifat atau ciri Kreditor (lihat konteks situasi, unsur pelibat wacana) yang demikian, dia dapat menentukan segala hal terkait dengan persyaratan peminjaman dana (kredit). Sebaliknya, sebagai pihak yang lemah, Debitor tidak berdaya untuk menolak atau keberatan atas syarat-syarat (isi perjanjian) yang telah dirumuskan oleh Kreditor. Penolakan atau keberatan atas isi surat perjanjian dapat berakibat pada ancaman bahwa pengajuan fasilitas kredit (dana pinjaman) tidak dapat dikuncurkan alias ditolak. Praktik sosial ini benar-benar menunjukkan bukti nyata, realitas sosial atau relasi kekuasaan pada kaum kapitalis yang lebih kuat (themorepowerful) untuk mendominasi kaum yang lebih lemah (the powerless), sehingga tercipta relasi yang tidak setara, tidak seimbang, atau keadaan inequality are enacted (Van Dijk, 2005: 352).

\section{SIMPULAN}

Dengan analisis wacana kritis, dapat diungkap hubungan antara wacana dan kekuasaan. Wacana yang berupa SPPK digunakan sebagai sarana untuk mempraktekkan kekuasaan kaum kapitalis (Kreditor) untuk mendominasi kaum yang lebih lemah secara finansial (Debitor). Dengan dominasi tersebut terjadi hubungan (relasi sosial) yang tidak seimbang (unequal relation) antara pihak yang mengikatkan diri pada surat perjanjian, SPPK. Ketidaksetaraan tersebut dapat diungkap dengan adanya ketidakseimbangan pada cara menentukan hal-hal yang diperjanjikan. Pasal-pasal yang mengatur syarat dan ketentuan umum pada SPPK yang hanya mengutamakan hak-hak Kreditor. Sebaliknya, hal-hal yang mengarah pada Debitor lebih bersifat pelaksanaan kewajiban, pengenaan sanksi, penalti, dan biaya administrasi. Sementara itu, tidak ada satu pasal pun dalam SPPK yang menyatakan sanksi atau kewajiban kepada Kreditor.

Ketidaksetaraan pada SPPK juga terlihat dari pemroduksisan teks yang hanya didominasi oleh Kreditor.Perumusan isi (pasal-pasal) syarat dan ketentuan umum yang mengikat kedua pihak tidak dilakukan secara bersama antara Kreditor dan Debitor atau dirundingkan terlebih dulu. Semua isi surat perjanjian tersebut hanya ditentukan (dirumuskan) oleh pihak Kreditor. Oleh karena itu, semua kepentingan Kreditor terkait dengan dana yang dipinjamkan kepada Debitor selalu terlindungi, sebaliknya tidak ada hak dan kepentingan Debitor yang tercantum pada SPPK. Dengan analisis wacana kritis, dapat diungkap bahwa prinsip berdiri sama tinggi dan duduk sama rendah antara pihak yang saling berjanji yang merupakan salah satu prinsip dalam pembuatan surat perjanjian telah diabaikan. Prinsip yang terjadi adalah pihak yang kuat (secara finansial) mendominasi atau menguasai pihak yang (secara finansial) lebih lemah. 


\section{UCAPAN TERIMA KASIH}

Artikel ini merupakan hasil penelitian mandiri yang dilaksanakan pada bulan Januari hingga Juni 2014. Penulis menyampaikan terima kasih kepada Rektor Universitas Jember, melalui Ketua Lembaga Penelitian Universitas, dan Dekan Fakultas Sastra Universitas Jember yang berkenan mengizinkan dan memberi kesempatan penulis untuk melakukan penelitian. Ucapan terima kasih juga disampaikan kepada para kolega (Prof. Dr. Samudji, M.A., Prof. Bambang Wibisono, M.Pd., Indah Wahyuningish, MA, Sabta Diana, MA, dan Riskia Setiarini, M.Hum.) yang telah memberikan masukan guna mempertajam hasil analisis.

\section{DAFTAR PUSTAKA}

Asher, Ronald.E., dan Simpson, J.M.Y. 2006. The Encylopedia of Language and Linguistics. Edisi kedua. Oxford Pergamon Press.

Cao, Deborah. 2007.Translating Law. UK: Multilingual Matters Ltd.

Creswell, John W., dan Clark, V.L.P. 2011. Designing and Conducting Mixed Method Research. Thousand Oaks, CA: Sage Publication.

Denscombe, Martyn. 2007. The Good Research Guide for Small-scale Social Research Project. Bekshire. Macgraw Hill Open University Press.

Fairclaugh, Norman, dan Wodak, Ruth. 1997. "Critical discourse Analysis". Dalam T.A. van Dijk (Editor). Discourse Studies: A Multidisciplinary Introduction, Vol. 2: Discourse as Social Interaction, London: Sage Publication. (hal. 258-284)

Halliday, Michael Alexander Kirkword, dan Hasan, Ruqaiyah. 1989. Language, Context, and Text: Aspects of Language in a Social-semiotic Perspective. Victoria: Deakin University Press.

Halliday, Michael Alexander Kirkword. 2004. An Introduction to Functional Grammar. London: Arnold.
Hornby, Albert Sidney. 1982. Oxford Advanced Dictionary of English. London: Oxford University Press.

Keshavarz, Mohammad Hossein, dan Zonoozi, Leila Alimadadi. 2011. “Manipulation of Ideology in Translation of Political Texts: a Critical Discourse Analysis Perspective". Journal of Language and Translation. Vol. 2 (1): 1-12.

Leech, Geografy.1983. Principles of Pragmatics. London: Longman

Mardikantoro, Hari Bakti. 2014. "Analisis Wacana Kritis pada Tajuk (anti)korupsi di Surat Kabar Berbahasa Indonesia". Litera, Vol. (2): 215-225.

Renkema, Jan. 2004. Introduction to Discourse Studies. Philadelpia: John Benjamins Publishing Company.

Sriyono. 2014. "Penerjemahan Tema pada Teks Hukum". Adabiyyat, Jurnal Bahasa dan Sastra.Volume13, (1): 66-93.

Subagyo, Paulus Ari. 2010. "Pragmatik Kritis: Paduan Pragmatik dengan Analisis Wacana Kritis". Jurnal Linguistik Indonesia. Vol. 28 (2): 177-187

Sudaryanto,2003. Metode dan Aneka Teknik Analisis Bahasa: Pengantar Penelitian Kebudayaan secara Linguistis. Yogyakarta: Duta Wacana University Press.

Subroto, D. Edi. 1992. Pengantar Metode Penelitian Linguisitk Struktural. Surakarta: Sebelas Maret University Press.

Thompson, Geoff. 2004. Introducing Functional Grammar. London: Oxford University Press.

Tim Pustaka Phoenix. 2010. Kamus Besar Bahasa Indonesia. Jakarta: PT Media Pustaka Phoenix.

van Dijk, Teun Andianus. 2005. "Critical Discourse Analysis". dalam Schriffin, D, Tannen, D., Hamilton, H.E. (Editor).The Handbook of Discourse Analysis. New York: Blackwell Publishers Ltd.

Wetherell, Margaret, Taylor, S., dan Yates, Simeon J. 2001. Discourse Theory and Practice. London: Sage. 